\title{
Determinants of foreign direct investment ownership mode choice: Evidence from Nordic investments in Central and Eastern Europe*
}

\author{
Jorma Larimo, Ahmad Arslan ${ }^{* *}$
}

This paper addresses the determinants of foreign direct investment (FDI) ownership mode choice of firms in Central and Eastern Europe (CEE) based on three most important theoretical paradigms of IB studies i.e. transaction cost economics, resource based view and institutional theory. The empirical analysis of 720 FDIs made by the firms from all four Nordic countries in CEE region during 1990-2007 revealed that the probability WOS formation was increased by the high $R \& D$ intensity of the industry of the investment, low target country risk, large economic size and high economic growth in the target country. The further in-depth analysis revealed that for FDIs made during 1990s, product diversity; while for FDIs made during 2000s, international experience and strength of market conforming values in the target country became significant determinants of ownership mode choice for Nordic FDIs.

Dieser Artikel befasst sich mit den Determinanten der Markteintrittsform von ausländischen Direktinvestitionen von Unternehmen in Mittel- und Osteuropa, basierend auf drei zentralen theoretischen Paradigmen, nämlich der Transaktionskostentheorie, dem Ressourcen-basierten Ansatz und der Institutionen-Theorie. Die empirische Analyse von 720 Direktinvestitionen von Unternehmen aus den vier nordischen Ländern in Mittel- und Osteuropa zwischen 1990 und 2007 ergab, dass die Wahrscheinlichkeit der Bildung von Tochtergesellschaften durch die hohe F\&E-Intensität der Branche, ein niedriges Risiko der Zielländer, eine große Wirtschaft und ein großes Wirtschaftswachstum der Zielländer steigt. Für ausländische Direktinvestitionen während der 1990er Jahre erwiesen sich die Produktvielfalt und in den 2000er Jahren die internationale Erfahrung und die Stärke von marktkonformen Werten im Zielland für die Markteintrittsform als ausschlaggebend.

Key Words: Central and Eastern Europe, Foreign Direct Investments, Ownership Mode Choice, and Nordic Firms.

\footnotetext{
Manuscript received: 26.2.12, accepted 23.10.12 (2 revisions)
}

** Jorma Larimo, Professor, Department of Marketing, Faculty of Business Studies, University of Vaasa, Finland, and Faculty of Economics and Business Administration, University of Tartu, Estonia.. Corresponding address: jorma.larimo@uwasa.fi

Ahmad Arslan, Assistant Professor, Department of Marketing, Faculty of Business Studies, University of Vaasa, Finland. Corresponding address: ahmad.arslan@uwasa.fi. 


\section{Introduction}

Firms face two important strategic choices when they enter new markets using foreign direct investment (FDI) as an entry strategy (Dikova/van Witteloostuijn 2007; Slangen/Hennart 2008). The first choice is referred to as establishment mode choice, where firms either opt to set up their subsidiaries from scratch (i.e. greenfield investments) or acquire an on-going concern (i.e. acquisitions) (Brouthers/Brouthers 2000; Slangen/Hennart 2008). The second choice is referred to as ownership mode choice in the international business (IB) literature, where the firms decide whether they intend to establish their operation alone (wholly-owned subsidiary i.e. WOS) or jointly manage the affiliates with local partner(s) (international joint venture i.e. IJV) (Hennart 1991; Agarwal 1994; Luo 2001; Brouthers 2002; Chen/Hennart 2002; Arslan/Larimo 2010). The ownership mode choice presents an important strategic decision for the firms and it has been a widely researched topic in IB studies (e.g. Delios/Beamish 1999;; Luo 2001; Chang/Rosenzweig 2001; Brouthers/Hennart 2007). It is important for academics as well as the managerial audience to understand the impacts of main determinants on ownership mode choice. A review of past studies on ownership mode choice of firms reveals that transaction cost economics (TCE) has been used as the theoretical basis for the analysis of its determinants in many cases (e.g. Gatignon/Anderson 1988; Kogut/Singh 1988; Hennart 1991; Delios/Beamish 1999; Makino/Neupert 2000; Meyer 2001; Brouthers 2002; Demirbag et al. 2007; Morschett et al. 2010). TCE proposes both host country and home country related determinants that influence the benefits and costs associated with choice between WOS or IJV. Past IB studies have also used the resource based view (RBV) (e.g. Mutinelli/Piscitello 1998; Chen/Hennart 2002; Chang/Rosenzweig 2001; Claver/Quer 2005; Herrmann/Datta 2006) and institutional theory (Yiu/Makino 2002; Xu et al. 2004; Dikova/van Witteloostuijn 2007; Arslan/Larimo 2010; Arslan 2011) as theoretical bases for the analysis of ownership mode choices of investing firms in their international markets.

It has been mentioned by management scholars that IB as a research area is multidisciplinary in nature (Brouthers/Hennart 2007), and IB decisions and strategies have been analysed in many cases by using multiple theoretical frameworks (Meyer/Peng 2005). Therefore, the main goal of our paper is to analyse the impacts of important determinants of FDI ownership mode choices of firms based on all three mentioned theories. This important issue is also signified by the fact that TCE, RBV and institutional theory have been operationalized by a similar range of variables in the past IB and market entry mode analysis studies (see e.g. Claver/Quer 2005; Brouthers/Hennart 2007; Dikova/van Witteloostuijn 2007; Arslan/Larimo 2010). Consequently, we also deem it important for our study to concentrate on ownership mode choice analysis of the firms to integrate theoretical arguments from all three above- 
mentioned theories. Moreover, some ownership mode choice determinants like economic size and parent firm product diversity have not been analysed in the CEE context specifically by the past IB studies. As our study attempts to adapt a comprehensive approach by integrating them, we argue that it significantly advances IB and market entry literature. Hence, our paper incorporates a range of ownership mode choice determinants found significant in past market entry mode analysis studies based on TCE, RBV and institutional theory.

The current study concentrates on the ownership mode choice analysis of the firms investing in host countries located in Central and Eastern Europe (CEE), because it offers a novel context for understanding different international market entry and management issues (Arslan/Larimo 2010). Most countries in the CEE region have a unique history in relation to the transition to a market economy system from socialism, as well as the development of relevant social institutions (e.g. Meyer 2001; Svejnar 2002; Meyer/Peng 2005; Arslan/Larimo 2010). The empirical setting of this study comprises FDIs made by Nordic (Finnish, Swedish, Danish and Norwegian) firms in CEE countries during the time period 1990-2007. It has been mentioned in past literature that the CEE region went through a period of relatively high uncertainty in the 1990s due to transition to market economies which also affected the strategies of foreign firms (Peng 2003). Therefore, in addition to the general analysis of ownership mode choices, the current paper also attempts to analyse whether there has been any change in the decisions made and impact of the selected variables on the ownership mode choice of early investments of Nordic firms (i.e. FDIs made during the 1990s) vs. later investments (i.e. FDIs made during the 2000s); this is expected to add further interest in this paper, as well as enhance its academic contribution.

Our study enriches IB as well as CEE specific literature by adapting a rather comprehensive approach to study FDI ownership mode choice of the firms from the Nordic region (representing small, open and highly internationalized economies) in CEE. Although the ownership mode choices of firms originating from a Nordic country in the CEE region have been addressed by Arslan and Larimo (2010), they primarily concentrated on impacts of institutional distance in the specific context of FDIs from only one Nordic country i.e. Finland. This paper uses an expanded dataset comprising FDIs made by the firms from all four Nordic countries (i.e. Finland, Sweden, Norway and Denmark), and it also attempts to address determinants of ownership mode choices from a variety of theoretical perspectives rather than only concentrating on institutional distance. Therefore, it is expected that the findings of this study can be more easily generalizable due to multiple home countries of the investing firms.

Our paper starts with an introduction, followed by the discussion about the theoretical background leading to the development study hypotheses. All the hypotheses are based on solid theoretical arguments from different theories as well as empirical findings of past IB studies. The next section introduces the 
data collection procedure, study sample discussion and statistical method used for the analysis followed by the presentation of study results and relevant discussion. The paper concludes with a summary discussion, and offers some managerial implications and directions for future research.

\section{Theoretical background and study hypotheses}

Past IB studies mention that several firm, industry and target country related variables are all important for the FDI ownership mode choice of the firms (e.g. Luo 2001). It has been mentioned earlier that most of the previous market entry studies have used TCE, RBV and institutional theory to analyse FDI ownership mode choices of the firms. Meyer and Peng (2005) in their review paper concentrating on management and IB strategies in the CEE region also found that only these three theories were used by the researchers analysing market entry mode strategies. They further observed that due to the specific nature of changes in the CEE region, as mentioned already in this paper, there is a need by the researchers to adopt a more comprehensive theoretical approach by integrating arguments from these theories while analysing different IB issues. We also support this observation by arguing that it is important to integrate key determinants of ownership mode choice to analyse this important market entry decision in the CEE region in a rather comprehensive manner. So far, no previous IB study concentrating on the CEE region (at least to our knowledge) has analysed the determinants of ownership mode choice based on these three theoretical bases.

It is further important to note that certain variables like R\&D intensity, parent firm product diversity, international experience, area and target country experience, target country risk, cultural distance, and strength of market conforming values in the target country have been used as key indicators in studies that utilized TCE, RBV as well as institutional theory as their theoretical bases for ownership mode choice analysis (see e.g. Hill et al. 1990; Claver/Quer 2005; Dikova/van Witteloostuijn (2007); Arslan/Larimo 2010). Therefore, we have incorporated those determinants found significant in past IB studies in our analysis by addressing them together in the context of FDIs made by Nordic Firms in the CEE region. Moreover, it is important to note that an important political-economic change that occurred in the CEE region during past two decades, along with the transition to market economy, has been that many countries have become members of the European Union (Zweynert/Goldschmidt 2006). Therefore, we also hypothesize EU membership as a determinant ownership mode choice of Nordic firms in the CEE region, along with the above-mentioned important firm, industry and country level determinants. Finally, as mentioned earlier, establishment mode is the other major choice for an investing firm when it enters a market using FDI mode. Therefore, we also 
hypothesize potential impact of establishment mode as being a determinant of FDI ownership mode choice.

We present the relevant theoretical discussion that leads to development of the study hypothesis in relation to a specific ownership mode choice determinant as follows.

\subsection{R\&D intensity}

$R \& D$ intensity is a frequently used measure of asset specificity, which is one of the key dimensions of TCE logic for the analysis (Zhao et al. 2004). Firms with a high level of R\&D intensity are likely to transfer a significant amount of knowledge to their subsidiaries. These firms are expected to face great difficulties in pricing the technology and enforcing the contracts with joint venture partners (Anderson/Gatignon 1986; Hennart 1991). Consequently, firms spending more on R\&D prefer to choose WOS in order to completely control their proprietary know-how and/or best exploit such know-how in their international markets (Gatignon/Anderson 1988; Padmanabhan/Cho 1996). Results in several previous empirical studies (e.g. Padmanabhan/Cho 1996; Cho/Padmanabhan 2005; Sun 1999; Chiao et al. 2010; Lee 2010) have supported the view that high R\&D intensity tends to increase the probability of firms to choose WOSs rather than IJVs. Moreover, in CEE specific studies, the empirical results regarding the impacts of R\&D intensity on the ownership mode choice have been mixed. Brouthers (2002), Dikova and van Witteloostuijn (2007), and Paul and Wooster (2008) found a non-significant impact of R\&D intensity on the ownership mode choice whereas results by Brouthers et al. (2003, 2008) discovered a positive relationship between R\&D intensity and higher degree of ownership. Based on significant support for the TCE based assumption of the positive relationship between R\&D intensity and degree of ownership chosen, as well as similar results in some CEE focused studies, we hypothesize:

H1: R\&D intensity is positively associated with the propensity of Nordic firms to choose WOS over IJV in CEE.

\subsection{Parent firm product diversity}

Parent firm product diversity is an important determinant of market entry and ownership mode choices that has been used in past IB studies that applied both TCE and RBV (see e.g. Hennart 1991; Tallman/Li 1996). It has been mentioned in previous IB and management literature that the highly concentrated firms more commonly own the needed product-specific knowledge (Hennart 1991; Burgel/Murray 2000). Therefore, based on product specific reasons, there is less need for a partner to the foreign unit of such firms. When the degree of diversification of the firms increases, the firms in many cases discover that they do not possess enough product-specific knowledge in all fields of industries that 
they operate in, in order to successfully manage the foreign subsidiary alone (Larimo 2000). Such product-specific knowledge is experiential and largely tacit (Slangen/Hennart 2007), and therefore it is costly to replicate such knowledge internally and hard to purchase in the market (Hennart 1991; Slangen/Hennart 2007). Therefore, it can be expected that the firms having more diversified operations may find partial ownership mode to be a more efficient tool to access such intermediate inputs (i.e. product-specific knowledge) as mentioned in the studies by Gomes-Casseres (1985) and Zejan (1988). The impact of the degree of diversification of the parent firms on the ownership mode choice has apparently been not been analysed specifically in any of the earlier CEE focused IB studies. However, based on the above mentioned argument from past general IB and market entry mode choice studies, we hypothesize:

$\mathrm{H} 2$ : Parent firm product diversity is negatively associated with the propensity of Nordic firms to choose WOS over IJV in CEE.

\subsection{International experience}

Experience of the internationalizing firms has been one of the key variables extensively addressed in IB studies to analyse ownership mode choice of the firms using both TCE and RBV (Brouthers/Hennart 2007). Experience is one of the tenets of the famous Uppsala model of internationalization developed by Johanson and Vahlne (1977) which posits that a firm's current behaviour is influenced by its past experience and knowledge. The more the firm operates in international markets, the more it accumulates knowledge about their foreign operations (Barkema et al. 1996). As firms accumulate more experience in international markets, they develop efficient processes and systems for managing their global operations (Anderson/Gatignon 1986; Larimo 2000). Consequently, as international experience increases, investing firms will be less likely to share their decision making with the local partner and may prefer WOSs over IJVs.

However it is important to note that past IB studies have reported mixed findings with regard to the effect of international experience on ownership mode choice of the firms. Several studies such as Padmanabhan and Cho (1999), Shi et al. (2001), Claver and Quer (2005) and Arslan and Larimo (2010) have indicated a non-significant relationship between international experience and choice of ownership. In some other studies like Chiao et al. (2010) and Lee (2010), the researchers found that international experience is positively associated with the probability of Taiwanese firms to choose WOSs in China. Moreover, Li and Meyer (2010) found a positive relationship of experience with WOSs' formation in FDIs made into developed countries, while they found it non-significant for the FDIs made into emerging and developing economies. From the studies focusing on the CEE region, Brouthers (2002) indicated a nonsignificant impact whereas Meyer (2001) and Brouthers et al. (2004) found a 
positive relationship. Dikova and van Witteloostuijn (2007) found that when EU based firms had more international experience, this increased the probability of choosing an IJV alternative. Dikova and van Witteloostuijn (2007) as well as $\mathrm{Li}$ and Meyer (2010) explain their results that international experience from developed countries is not as applicable in emerging economies like CEE because the market environment in the latter is much different and in several CEE countries there have been many changes during the years. Based on the above discussion, two alternative choices emerge for the expected ownership mode choice of Nordic firms in CEE. Therefore, we hypothesize:

H3a: International experience is positively associated with the propensity of Nordic firms to choose WOS over IJV in CEE.

$\mathrm{H} 3 \mathrm{~b}$ : International experience is negatively associated with the propensity of Nordic firms to choose WOS over IJV in CEE.

\subsection{Area and target country experience}

It is important to note that past IB studies using TCE and RBV logics referred to the importance of area and target country experience along with general international experience for the analysis of market entry mode choices of the firms (e.g. Dowell/Killaly 2009). Firms having no or limited experience of operation in a particular market or in the neighbouring countries (area) usually lack the knowledge of local conditions (Hennart 1991). Local firms have gained this knowledge through doing business in the local market. Local knowledge is therefore embedded in the local firm and is costly to replicate or to purchase (Hennart/Park 1993). Therefore, it can be expected that firms expanding to new countries where they have no previous operations (i.e. lack of local knowledge) are more prone to prefer IJVs' formation in order to acquire the required area and target country specific knowledge.

On the other hand, firms with prior investment experience in the target country or in the target area have gradually accumulated such knowledge and therefore tend to be less dependent on local partners. Consequently, these firms are less likely to share the ownership of the subsidiary with local partners. Hennart (1991) found that Japanese investors having greater target country (U.S.) experience are more likely to choose WOS over IJV. His finding was supported by several China-focused empirical studies, e.g., Luo (2001), Claver and Quer (2005), and Wei et al. (2005). However, Shi et al. (2001) posited that target country experience of Hong Kong firms is negatively associated with the probability of choosing WOS. Recently, a similar result has also been found in the study by Li and Meyer (2010). Their results indicated that especially in China, previous experience increased the probability of IJV formation. Two of the CEE focused studies have analysed the role of the area and/or target country specific experience on ownership mode selection. Meyer (2001) found in his study that area specific experience had a non-significant influence on ownership 
mode choice whereas Dikova and van Witteloostuijn (2007) found a positive relationship between area specific experience and the preference for WOS formation. Based on the above discussion, both IJV and WOS choice in relation to area and target country specific experience of the firms have received support in different past IB studies. Therefore, we hypothesize:

H4a: Area specific experience is positively associated with the propensity of Nordic firms to choose WOS over IJV in CEE.

H4b: Area specific experience is negatively associated with the propensity of Nordic firms to choose WOS over IJV in CEE

H5a: Target country experience is positively associated with the propensity of Nordic firms to choose WOS over IJV in CEE

$\mathrm{H} 5 \mathrm{~b}$ : Target country experience is negatively associated with the propensity of Nordic firms to choose WOS over IJV in CEE

\subsection{Target country risk}

One of the key issues addressed in TCE as well as RBV and institutional theory is uncertainty and how it can impact entry mode choices of the firms (Brouthers/Hennart 2007; Estrin et al. 2009). In the case of high uncertainty, transaction cost logic recommends a higher level of vertical integration. Due to bounded rationality, anticipation of all future contingencies for which adaptations of a contract with a partner may be required is difficult under conditions of strong uncertainty. Hence the internalization of the activity may contribute to the absorption of external uncertainty (Klein et al. 1990; Agarwal 1994). However, transaction cost reasoning ignores the advantages of strategic flexibility (Brouthers et al. 2008) and from the RBV perspective, high country risk implies the need to save firm resources and suggests avoidance of WOS (Agarwal/Ramaswami 1992; Contractor/Kundhu 1998). Target country risk has been used as a measure for external uncertainty in many past IB studies (Zhao et al. 2004; Brouthers/Hennart 2007; Morschett et al. 2010).

According to the results of the meta-analysis of market entry literature conducted by Morschett et al. (2010), country risk was included in 28 studies and the results of the analysis gave strong support for the increased preference of the IJV alternative in cases of high country risk. Empirical results of past CEE focused studies also support the general results as Brouthers (2002) and Brouthers et al. (2003) found that higher investment (country) risk increased preference for IJV formation rather than WOSs. Therefore, we also hypothesize:

H6: Target country risk is negatively associated with the propensity of Nordic firms to choose WOS over IJV in CEE. 


\subsection{Cultural distance}

Culture and cultural distance between the home country of the investing foreign firm and the target country of the investment, have been intensively addressed in past IB studies addressing ownership mode choice of firms (Morschett et al. 2010). Cultural distance has been referred to as the differences in national culture characteristics of the home and of the target country of investing firms (Hennart/Larimo 1998). Cultural distance influences the perceptions of investing firms regarding cost and uncertainty of alternative ownership modes in foreign markets (Kogut/Singh 1988; Padmanabhan/Cho 1996; Slangen/Hennart 2007). Cultural distance has been used in most past IB studies as an extension of TCE and institutional theory for the analysis of market entry and ownership mode choices (Kogut/Singh 1988; Makino/Neupert 2000; Yiu/Makino 2002). There have been two opposing perspectives concerning the impacts of cultural distance on ownership mode choice of firms in past IB studies. On one hand, it has been argued that cost and uncertainty in shared ownership structure are greater in culturally distant target countries due to volatility of environment in the target country (Brouthers/Brouthers 2000). Accordingly, firms investing in culturally distant target countries are more likely to prefer formation of WOS in order to exert greater control over their subsidiaries in order to minimize transaction costs (Hill et al. 1990).

Further on, Barkema et al. (1996) posited that the cooperation with local partners involves "double-layered" acculturation whereby investing firms would have to tackle cultural difference of customers and moreover, cope with corporate cultural difference of the local partner. This suggests that investing firms could use an internalized governance form to avoid the complexity stemming from "double-layered" acculturation. On the other hand, the relationship of cultural distance and ownership mode choice has also been explained in the context of the investing firm's need for risk reduction. Firms operating in culturally distant target countries frequently require greater flexibility. Therefore, the formation of IJV offers investing firms a viable option to commit fewer resources and consequently reduce the risk (Tihanyi et al. 2005). Empirical evidence on the relationship between cultural distance and ownership mode choice has also been mixed and inconclusive in past IB studies. While Kogut and Singh (1988) revealed that firms investing in culturally distant nations have a greater preference for IJVs over WOS, Taylor et al. (1998) found that American firms tend to opt for IJV in countries with a culture similar to United States. A recent study of the choice of entry mode by meta-analysing data from 72 studies showed that cultural distance is non-significantly related to ownership mode choice (Morschett et al. 2010). In CEE focused studies, Brouthers et al. (2004) found a positive relationship between high cultural distance and preference for WOS ownership mode by the investing firms. Based on the discussion presented above, two alternative choices emerge for the 
expected impacts of cultural distance on the ownership mode choice of Nordic firms in the CEE region. Therefore, we hypothesize:

H7a: Cultural distance is positively associated with the propensity of Nordic firms to choose WOS over IJV in CEE

H7b: Cultural distance is negatively associated with the propensity of Nordic firms to choose WOS over IJV in CEE

\subsection{Economic size of the target country}

The attractiveness of a foreign market depicted by its large economic size has been a predominant factor in market selection as well as ownership mode choice of the firms from the TCE perspective (e.g. Brouthers/Brouthers 2002; Cui/Jiang 2009). Usually firms are expected to enter attractive markets via WOS because it is expected that this alternative provides the greatest long term profit potential (see e.g. Taylor et al. 1998; Brouthers 2002). Countries that are characterized by higher market attractiveness are seen to have greater potential to absorb additional capacity, which provides an opportunity to improve firm efficiency by capitalizing on the new opportunities offered there. In markets with high market attractiveness, firms are expected to use vertical integration so they can gain economies of scale and secure a long-term market presence (Agarwal/Ramaswami 1992; Brouthers 2002).

Large market size is assumed to lead to an enhanced resource commitment in the country but the expected increased returns will compensate the higher risks associated with the greater commitment of resources (Agarwal 1994). Higher returns are expected to come from the opportunity to gain economies of scale (Agarwal/Ramaswami 1992), based on the assumption that a high proportion of the cost of internationalization is fixed (Buckley/Casson 1996; Chen/Hu 2002). Following TCE rationale, market size can also be seen as a proxy for transaction frequency, which also enhances the firm's propensity to internalize (Williamson 1985). The empirical results of past IB studies about the impact of this important variable on ownership mode choice of firms are again quite mixed. Results in some studies like Barkema and Vermeulen (1998) support the positive relationship but results in other studies like in Lu (2002) indicate a nonsignificant relationship and some results like in Gomes-Casseres (1989) and Herrmann and Datta (2002) indicate a negative relationship. Therefore the results of the meta-analysis made by Morshett et al. (2010) did not provide support for the positive relationship between market size and WOS choice. None of the studies focusing on the CEE region so far have analysed this relationship specifically. Therefore, the current study advances CEE focused literature by being the first one to advance TCE application by addressing the impact of economic size on ownership mode choice. Based on the discussion, we hypothesize: 
H8: Target country economic size is positively associated with the propensity of Nordic firms to choose WOS over IJV in CEE.

\subsection{Economic growth in target country}

An important indicator of the attractiveness of target country market used in past IB studies following TCE logic is economic growth in the target country (e.g. Larimo 1993; Meyer/Peng 2005). Economic growth in the target country, however, differs somewhat from other facets of market attractiveness e.g. from market size due to its dynamic nature. As an implication of this, economic growth is expected to lead to a negative relationship with the WOS alternative, because using the IJV alternative the investing company can avoid the opportunity costs associated with delayed entry (Hennart/Larimo 1998).

Empirical results concerning the influence of economic/market growth on WOS ownership choice are again mixed i.e. results in some studies indicate a positive and in some studies a negative relationship. The meta-analysis by Morschett et al. (2010) indicates, however, that the assumption of a negative relationship between market growth and an IJV ownership mode receives statistically significant support. In CEE focused studies of ownership mode choice, Arslan and Larimo (2010) found high economic growth to result in choice of WOSs by Finnish firms, while Dikova and van Witteloostuijn (2007) indicated a nonsignificant influence of economic growth on the ownership mode choice of Dutch firms in the CEE region. Therefore, based on the transaction cost theory argument, the findings of Arslan and Larimo (2010) and meta-analysis by Morschett et al. (2010), it is expected that:

H9: Target country economic growth is positively associated with the propensity of Nordic firms to choose WOS over IJV in CEE.

\subsection{Strength of market conforming values in the target country}

Institutional theory proposes that FDI choices and decisions of internationalizing firms are considerably influenced by the effectiveness of market economy institutions of their target countries (e.g. Child/Tsai 2005; Meyer/Peng 2005). The quality of institutions and resulting strength of market conforming values in the target country are important determinants of the firm's foreign market entry decisions including FDI ownership mode choices (Arslan 2011). With respect to FDI ownership mode choices, restriction on ownership and entry mode options by target governments due to developing market economy institutions (e.g. Khanna/Palepu 2010) is a major concern for investing foreign firms (e.g. Gomes-Casseres 1989; Makino/Beamish 1998; Delios/Beamish 1999; Trevino et al. 2008). On the other hand, the results by Child and Tsai (2005) indicate that when firms operate favourable external circumstances, they tend to commit more resources to the target country e.g. formation of WOSs. 
Some past IB studies have also mentioned that lesser restrictions on ownership options can motivate firms to prefer WOSs over JVs (e.g. Chung/Beamish 2005). Finally, Li et al. (2007) in their study also found that if market conforming values in the target country are strong, then the institutions become less restrictive and WOSs become more acceptable in the target country. Consequently, in a target economy with strong market conforming values, acquisitions of local firms and formation of WOSs can be a preferred strategy of firms (Arslan 2011). Based on the above discussion, we hypothesize:

H10: Strong market conforming values in the target country are positively associated with the propensity of Nordic firms to choose WOS over IJV in CEE.

\subsection{EU membership}

An important issue stressed by the institutional theory refers to the level of advancement of the institutional environment in a particular target country (Peng 2003). The more advanced the environment is, the more stable the environment is, and this could be expected to lead to increasing preference for a WOS alternative. Institutional development can be used as an indicator of the progress of transition, , but EU membership can be used as another indicator of progress, because the EU demands certain level of progress and stability before a new applicant country is accepted as a member. Dikova and van Witteloostuijn (2007) present somewhat different views about the impact of institutional advancement on ownership mode. They state that in an underdeveloped institutional environment characterized by weak property rights, regimes' WOS modes are more efficient because they reduce the transaction costs of unwanted dissemination. In transition countries with better institutional safeguards offering greater property rights' protection, lower ownership modes are more efficient as the risk of asset expropriation is less and costly governance structures do not need to be constructed to protect assets (Delios/Beamish 1999). The empirical results by Dikova and van Witteloostuijn (2007) indicated weak support for their hypothesis of a positive relationship between institutional advancement and IJV mode. However, Arslan and Larimo (2010) did not find EU membership as a significant variable for the ownership strategy of Finnish firms in the CEE region. Based on the discussion presented, the past literature offers different perspectives about the impacts of EU membership of a target CEE country on the ownership mode choice of investing firms. However, for the empirical part of this study, we hypothesize:

H11: EU membership of a target country is positively associated with the propensity of Nordic firms to choose WOS over IJV in CEE. 


\subsection{Establishment mode}

On a priori grounds, the level of equity selected for a foreign subsidiary should not hinge on whether entry is through greenfield investment or through acquisition mode. The degree of ownership mode choice depends for example on the parent's need for providing incentives to a supplier of complementary inputs. These inputs can be supplied either via a greenfield IJV or partial acquisition. Earlier IB studies like Hennart and Park (1993) and Hennart and Larimo (1998) focusing on FDIs made into the USA have supported the nonsignificant relationship between establishment mode and degree of ownership. Some other studies like Gomes-Casseres (1985) and Larimo (1993) have indicated that staged ownership changes are more common in cases where the investment has been made using acquisition mode than when when greenfield mode has been used. However, past IB studies did not indicate any clear support that at entry stage firms tend to either prefer partial acquisitions or greenfield IJVs, compared to full acquisitions or greenfield WOSs by investing firms. Thus, we hypothesize that:

H12: Establishment mode choice is non-significantly associated with the ownership mode choice of the Nordic firms in CEE.

\section{Methodology, sample and operationalization of variables}

\subsection{Statistical method}

Since the dependent variable in the study is dichotomous (WOS vs. IJV), binomial logistic regression analysis is used to analyse the impact of the selected independent variables on the ownership mode choice. Binomial logistic regression analysis has been frequently used in the past IB studies addressing the ownership mode choice of firms in their international markets (e.g. Gatignon/Anderson 1988; Hennart/Larimo 1998; Dikova/van Witteloostuijn 2007; Kaynak et al. 2007; Arslan/Larimo 2010). Therefore, binomial logistic regression has proved to be a useful statistical technique to analyse FDI ownership mode choices of the investing firms in previous IB studies and this study also employs this statistical technique. The regression coefficients estimate the impact of independent variables on the probability that the investment will be a WOS, with a positive coefficient indicating that an independent variable increases the probability of a WOS. In general, the terms of the model can be expressed as

$P(y i=1)=1 /(1+\exp (-a-X i B))$

where $y i$ is the dependent variable, $\mathrm{Xi}$ is the vector of the independent variables for the $i$ th observation, $a$ is the intercept parameter and $B$ is the vector of regression coefficients (Amemiya, 1981). We estimated our models with the Statistical Program for Social Sciences, IBM SPSS 20. 


\subsection{Operationalization of variables}

The dependent variable in this study is captured by a dummy variable which takes the value 1 if the firm owned $95 \%$ or more of the subsidiary equity (i.e. WOS), and zero if it owned at least $10 \%$, but no more than $94 \%$ of equity (i.e. IJV). The 95\% cut-off point was used in several earlier IB studies addressing ownership mode choice and this study also follows their track (e.g. Gatignon/Anderson 1988; Hennart 1991, Hennart/Larimo 1998; Arslan/Larimo 2010). The operationalization of the independent variables, data sources, references of earlier studies where similar operationalizations have been used and the expected signs are presented in Table 1.

\subsection{Data collection and sample description}

The empirical data for the study are based on an internal FDI databank encompassing the investment activities of the firms (both large and small) from the Nordic region in their international markets. This database has been developed and updated constantly during the past many years. The data have been collected mainly from the annual reports and press releases of the investing Nordic firms, but also supplemented with the data gathered from articles in leading local business magazines and direct contact with several of the investing firms. It should also be mentioned that this database includes information of post investment activities like divestment, sell-off and change of ownership in many cases. Therefore, it can be said that it is a unique and reliable source of FDI activities of Nordic firms.

In total, approximately 1200 manufacturing FDIs made by Nordic firms during 1990-2007 could be identified by the authors. However, there is missing information especially related to the year of investment, parent firm product diversity and experience; hence the dataset for this study consists of 720 manufacturing investments made by Nordic firms in the CEE region during the study time period. The sample focuses on the ownership mode at entry (i.e. possible later changes in the ownership arrangement of the same investment are not included). Most of the IJVs in the sample were joint units with local partner(s) but the sample also included some units where there were two Nordic partners in addition to the local partner, and in only extremely few cases the other foreign partner was from a third country. A great majority of the FDIs were made by relatively large Nordic firms, having operations in several fields of industries (on average, firms operated on approximately 12 SIC four digit code fields) and they had extensive previous international FDI experience. However, the sample also included FDIs made by SMEs and firms having less international experience - the reviewed FDIs were the first ones or among the first FDIs made by the sample firm. Moreover, in about $70 \%$ of the cases, the firms had previously reviewed FDIs' experience from other CEE countries. In somewhat fewer cases (two-thirds), firms had an earlier FDI in the target 
country (and mean of 2.75 years' experience) and somewhat less than one-third of the sample consisted of first manufacturing investments made by the firms in the target country. The mean cultural distance between the home and target countries of investments was 2.51 and mean country risk rating was 48.69 (on a scale from 0 to 100).

Table 1: Variables operationalization

\begin{tabular}{|c|c|c|c|}
\hline Variables & Operationalization & Reference(s) & $\begin{array}{c}\text { Expected } \\
\text { sign }\end{array}$ \\
\hline $\begin{array}{l}\text { 1. R\&D } \\
\text { intensity }\end{array}$ & $\begin{array}{l}\text { A classification of various } 4- \\
\text { digit SIC industries into three } \\
\text { categories based on their value } \\
\text { added figures }\end{array}$ & $\begin{array}{l}\text { Hennart and Larimo } \\
\text { (1998); Chen and } \\
\text { Hennart (2002); } \\
\text { Larimo (2003) }\end{array}$ & $\mathrm{H} 1:+$ \\
\hline $\begin{array}{l}\text { 2. Parent firm } \\
\text { product } \\
\text { diversity }\end{array}$ & $\begin{array}{l}\text { The number of 4-digit SIC } \\
\text { codes in which the company } \\
\text { was operating based on the } \\
\text { annual reports and websites of } \\
\text { the firms. }\end{array}$ & $\begin{array}{l}\text { Hennart and Larimo } \\
(1998) \text {; Vermeulen } \\
\text { and Barkema (2001); } \\
\text { Larimo (2003) }\end{array}$ & H2: - \\
\hline $\begin{array}{l}\text { 3. International } \\
\text { experience of } \\
\text { the investing } \\
\text { firm }\end{array}$ & $\begin{array}{l}\text { The number of foreign } \\
\text { manufacturing investments } \\
\text { made by the company before } \\
\text { the reviewed investment. }\end{array}$ & $\begin{array}{l}\text { Gatignon and } \\
\text { Anderson (1988); } \\
\text { Andersson and } \\
\text { Svensson (1994) }\end{array}$ & $\begin{array}{l}\text { H3a: + } \\
\text { H3b: - }\end{array}$ \\
\hline $\begin{array}{l}\text { 4. Area } \\
\text { experience }\end{array}$ & $\begin{array}{l}\text { A dummy variable having a } \\
\text { value of } 1 \text { if the investing firm, } \\
\text { prior to the reviewed FDI, had } \\
\text { one or more manufacturing } \\
\text { FDIs in some other CEE } \\
\text { country and } 0 \text { if the company } \\
\text { did not }\end{array}$ & & $\begin{array}{l}\text { H4a: + } \\
\text { H4b: - }\end{array}$ \\
\hline $\begin{array}{l}\text { 5. Target } \\
\text { country } \\
\text { experience of } \\
\text { the investing } \\
\text { company }\end{array}$ & $\begin{array}{l}\text { The experience in years from } \\
\text { the first manufacturing } \\
\text { investment of the firm in the } \\
\text { target country. }\end{array}$ & $\begin{array}{l}\text { Hennart and Park } \\
\text { (1993); Andersson } \\
\text { and Svensson (1994); } \\
\text { Hennart and Larimo } \\
\text { (1998); Larimo } \\
\text { (2003); Cho and } \\
\text { Padmanabhan (2005) }\end{array}$ & $\begin{array}{l}\text { H 5a: + } \\
\text { H 5b: - }\end{array}$ \\
\hline $\begin{array}{l}\text { 6. Target } \\
\text { country risk }\end{array}$ & $\begin{array}{l}\text { Euromoney country risk index } \\
\text { (scale } \\
1 \text { for very high risk and } 100 \text { for } \\
\text { extremely low risk; } 100 \text { minus } \\
\text { the risk index value is used in } \\
\text { the statistical analysis) }\end{array}$ & $\begin{array}{l}\text { Cosset and Roy } \\
\text { (1991); Delios and } \\
\text { Beamish (1999); } \\
\text { Click (2005); Arslan } \\
\text { (2011) }\end{array}$ & H 6:- \\
\hline
\end{tabular}




\begin{tabular}{|c|c|c|c|}
\hline $\begin{array}{l}\text { 7. Cultural } \\
\text { distance }\end{array}$ & $\begin{array}{l}\text { Cultural distance is measured } \\
\text { by Kogut and Singh's (1988) } \\
\text { composite index, which is } \\
\text { based on difference between } \\
\text { Nordic countries and China } \\
\text { along four dimensions of } \\
\text { culture identified by Hofstede } \\
(1980) \text {. }\end{array}$ & $\begin{array}{l}\text { Brouthers and } \\
\text { Brouthers (2000); } \\
\text { Larimo (2003); Ruiz- } \\
\text { Moreno et al. (2007) }\end{array}$ & $\begin{array}{l}\text { H7a: + } \\
\text { H7b: - }\end{array}$ \\
\hline $\begin{array}{l}\text { 8. Economic } \\
\text { size }\end{array}$ & $\begin{array}{l}\text { Economic size of the target } \\
\text { country } \\
\text { based on the total GDP in the } \\
\text { year of the investment } \\
\text { (UNCTAD) }\end{array}$ & $\begin{array}{l}\text { Hennart and Larimo } \\
\text { (1998); Vermeulen } \\
\text { and Barkema (2001); } \\
\text { Larimo (2003) }\end{array}$ & H8: + \\
\hline $\begin{array}{l}\text { 9. Economic } \\
\text { growth }\end{array}$ & $\begin{array}{l}\text { Economic growth (\% of GDP } \\
\text { growth) in the target country of } \\
\text { the investment in the year } \\
\text { preceding the investment } \\
\text { (UNCTAD) }\end{array}$ & $\begin{array}{l}\text { Hennart (1991); } \\
\text { Gomes-Casseres } \\
(1990) \text {; Brouthers } \\
\text { and Brouthers }(2000)\end{array}$ & H9: + \\
\hline $\begin{array}{l}\text { 10. Strength of } \\
\text { Market } \\
\text { Conforming } \\
\text { Values }\end{array}$ & $\begin{array}{l}\text { Average of country rating in } \\
\text { item ownership restrictions } \\
\text { (Scores from 1-10) and country } \\
\text { scores in the item: Foreign } \\
\text { Investors are free to acquire } \\
\text { control in local firms (Scores } \\
\text { from 1-10) (Sources: } \\
\text { Economic Freedom of the } \\
\text { World annual reports and } \\
\text { World Competitiveness } \\
\text { Yearbooks) }\end{array}$ & Arslan (2011) & H10: + \\
\hline $\begin{array}{l}\text { 11. EU } \\
\text { membership }\end{array}$ & $\begin{array}{l}\text { A dummy variable having a } \\
\text { value of } 1 \text { if the target country } \\
\text { was an EU member country at } \\
\text { the time of investment and } 0 \text { in } \\
\text { other cases }\end{array}$ & $\begin{array}{l}\text { Arslan and Larimo } \\
(2010)\end{array}$ & H11: + \\
\hline $\begin{array}{l}12 . \\
\text { Establishment } \\
\text { mode }\end{array}$ & $\begin{array}{l}\text { A dummy variable where } 1 \\
\text { stands for acquisitions and } 0 \\
\text { for greenfield investments }\end{array}$ & $\begin{array}{l}\text { Cho and } \\
\text { Padmanabhan } \\
(2005) ; \text { Kim and } \\
\text { Gray (2008) }\end{array}$ & H12: NS \\
\hline
\end{tabular}

Furthermore, out of the FDIs, approximately 53\% were acquisitions and $47 \%$ Greenfield investments and a clear majority of the reviewed FDIs were made in the 1990s (almost 70\%) and the rest (approx. 30\%) in the 2000s. Finally, out of the total sample, $45 \%$ FDI were made by Finnish firms, $32 \%$ by Swedish firms, and the rest, $23 \%$, by Danish and Norwegian firms. 


\section{Empirical findings and discussion}

We conducted the correlation analysis before logistic regression tests (see Appendix 1) in order to detect any multicollinearity among independent variables. As shown in the results, the bivariate correlation of international experience and parent firm product diversity was high (0.77). This value is over the cut-off point of .7, indicating a potential for multicollinearity (Pallant 2007). Additional multicollinearity diagnostic (tolerance and variance inflation factor (VIF)) was conducted. According to Belsley et al. (1980) and Wetherill (1986), the VIF value should not exceed 10. In this study the VIF values were even lower than 5 and thus, the potential collinearity among variables is not expected to influence the logistic regression results of this study.

The results of the binary logistic regression are presented in table 2. The estimated coefficients represent the relationship between the independent variables and the probability of choosing WOS over IJV. A positive and significant regression coefficient indicates that an increase in the independent variable associates with an increased probability of WOS formation by the investing firm. Accordingly, a negative and significant regression coefficient depicts that a particular independent variable is associated with increased probability of IJV formation rather than a WOS. Model 1 shows the regression results for the full sample. Model 2 shows the empirical results for the subsample of FDIs made in the 1990s and model 3 shows the investments made in the 2000s.

Table 2 shows that Model 1 has a good explanatory power because the chisquare value is significant at $\mathrm{p}<0.001$ level. Hair et al. (1998) recommend analysing the fit of the logistic regression model to the data by using correct classification rate criteria. The classification rate is computed as $a^{2}+(1-a)^{2}$, where $a$ is the proportion of WOS in the sample. In our study, the base score is 50.5. Model 1 correctly classified $64.6 \%$ of the cases. Usually some $25 \%$ increase compared to the baseline model is regarded as the goal. This is not reached, but this has been the case also in several other ownership mode studies. The -2 Log likelihood of the model is 899.415 and Nagelkerke R square is 0.165 .

The results of the full sample regression model indicate that high R\&D intensity, high target country economic growth rate, and large target country market size increase the probability of WOSs' formation, while high target country risk increases the probability of IJVs' formation by investing Nordic firms in CEE. As discussed earlier that high R\&D intensity has been linked to WOSs' choice by investing firms in some general previous IB studies (e.g. Cho/Padmanabhan 2005; Lee 2010) and as well as CEE specific studies (e.g. Brouthers et al. 2008). Therefore, our study confirms their findings and offers support for hypothesis 1 . The choice of IJV in high risk target countries can be explained by referring to 
the investing firm's desire to share risks and costs in a risky environment (e.g. Agarwal/Ramaswami 1992; Brouthers et al. 2008). This finding supports hypothesis 6 of the study.

The finding concerning large economic size of the target country increasing the probability of WOSs' formation is similar to findings of the previous studies like Agarwal and Ramaswami (1992) and Brouthers (2002), and also supports hypothesis 8 of our study. We further observe that high economic growth in the target country increases the probability of choice of WOSs by investing Nordic firms. This result supports the findings of previous IB studies addressing impacts of this variable generally (e.g. Morschett et al. 2010) as well as in a CEE specific context (Arslan/Larimo 2010) and the result gives support for hypothesis 9 of our study.

Table 2: Logistic regression estimates of ownership mode choice (WOS=1)

\begin{tabular}{|l|c|c|c|}
\hline Variable & $\begin{array}{l}\text { Model 1: Full } \\
\text { sample }\end{array}$ & Model 2: 1990s & Model 3: 2000s \\
\hline R\&D intensity & $0.289^{* *}$ & 0.130 & $0.497^{* *}$ \\
\hline $\begin{array}{l}\text { Parent firm product } \\
\text { diversity }\end{array}$ & -0.022 & $-0.031^{*}$ & 0.010 \\
\hline $\begin{array}{l}\text { International } \\
\text { experience }\end{array}$ & -0.005 & 0.005 & $-0.018^{* *}$ \\
\hline Area experience & 0.003 & 0.532 & -0.663 \\
\hline $\begin{array}{l}\text { Target country } \\
\text { experience }\end{array}$ & 0.194 & -0.010 & 0.057 \\
\hline Target country risk & $-0.017^{* *}$ & $-0.020^{* *}$ & -0.010 \\
\hline Cultural distance & 0.102 & & 0.253 \\
\hline Economic size & $0.272^{* *}$ & -0.145 & $0.499^{*}$ \\
\hline Economic growth & $0.040^{* * *}$ & $0.028^{*}$ & 0.074 \\
\hline Market conf. values & 0.017 & 0.019 & $0.232^{*}$ \\
\hline EU membership & 0.004 & $-0.645^{* * *}$ & -0.112 \\
\hline Establishment mode & $-0.662^{* * *}$ & & $-0.940^{* * *}$ \\
\hline Finland dummy & 0.356 & 0.263 & 0.084 \\
\hline Sweden dummy & 0.280 & & - \\
\hline
\end{tabular}




\begin{tabular}{|l|c|c|c|}
\hline $\boldsymbol{N}($ WOS $)$ & $720(334)$ & $516(211)$ & $204(123)$ \\
\hline Model $\boldsymbol{x}^{\mathbf{2}}$ & $94.958^{* * *}$ & $52.050 * * *$ & $51.424 * * *$ \\
\hline$-\mathbf{2} \log$ likelihood & 899.415 & 646.058 & 222.671 \\
\hline Nagelkerke $\boldsymbol{R}^{\mathbf{2}}$ & 0.165 & 0.129 & 0.301 \\
\hline $\begin{array}{l}\text { Correctly classified } \\
(\%)\end{array}$ & 64.6 & 63.8 & 68.1 \\
\hline$*$
\end{tabular}

${ }^{*} \mathrm{p} \leq 0.1,{ }^{* *} \mathrm{p} \leq 0.05,{ }^{* * *} \mathrm{p} \leq 0.01$

Establishment mode appears to be most significant variable for all three models of the study. Although we expected no significant relationship between establishment and ownership mode choices, the results show the acquisition establishment mode increases the probability of IJV by Nordic firms in the CEE region i.e. use of partial acquisition as entry mode (Meyer 2002). Moreover, similar results about the impact of establishment mode choice on ownership strategy were found by Arslan and Larimo (2010) in their study concentrating on FDIs made by Finnish firms in the CEE region. Therefore, it can be argued that the establishment and ownership mode choices of Nordic firms are rather similar to each other due to relatively common home country characteristics, as all Nordic countries represent small, open, developed and highly internationalized economies.

It is rather interesting to observe that several determinants like international experience, area experience and target country experience of investing firms, parent firm product diversity, cultural distance and strength of market conforming values in the target country, are found to be non-significant in the ownership mode choice analysis of the full sample. One explanation for the nonsignificance of these important variables can be offered by referring to sample heterogeneity, as it included firms of different sizes, backgrounds and levels of experience originating from the Nordic countries. Moreover, as the study covers a time period of 17 years, certain important changes occurred during this time in CEE, as transition to market economy was successful in some countries more than others (e.g. Zweynert/Goldschmidt 2006; Kshetri 2010). We would like to further mention that non-significance of these variables solidifies the arguments in favour of CEE specific studies, as past IB studies that concentrated on other geographical regions found them significant for ownership mode choice of firms (see e.g. Hill et al. 1990; Taylor et al. 1998; Brouthers et al. 2008; Chiao et al. 2010; Lee 2010). Finally, the country dummies for Finland and Sweden are also non-significant in the regression results, showing no specific ownership choice behaviour of the firms originating from these countries. 
In order to analyse the study results in more detail, the sample was divided into two subsamples - FDIs made during the 1990s in model 2 and FDIs made during the 2000s in model 3 (see table 2). The significance level of model 2 is good $(\mathrm{p}<.001)$ but Nagelkerke R Square (.129) and ratio of correctly classified cases $(63.8 \%)$ are only satisfactory. The results indicate that three determinants found significant in the full sample are also significant in the first subsample i.e. economic growth in the target country, target country risk, and establishment mode. Furthermore, all three variables also have the same signs as in model 1 and also the levels of significance are very close to the levels in model 1 . However, in Model 2, R\&D intensity and economic size of target country are non-significant, though they were found significant for the full sample of study. Model 2 further shows parent firm product diversity to be mildly significant and the regression coefficient indicates high parent firm product diversity being negatively associated with choice of WOSs supporting hypothesis 2 of study. Therefore, we receive partial support for hypothesis 2 of the study due to sample division and detailed analysis. As mentioned in earlier discussion, the parent firms with less product diversity more commonly own the needed productspecific knowledge (Hennart 1991; Burge/Murray 2000). Therefore, based on product specific reasons, there is less need for a partner to the foreign unit of such firms. Moreover, when the degree of diversification of these firms increases, they may find out that they lack product-specific knowledge in certain fields of industries that they operate in, in order to successfully manage the foreign subsidiary alone (Larimo 2000). Such product-specific knowledge is experiential and largely tacit (Slangen/Hennart 2007), and therefore it is costly to replicate such knowledge internally and hard to purchase in the market (Hennart 1991; Slangen/Hennart 2007). As the impact of product diversification of the investing firms on the ownership mode choice has not been analysed in any of the earlier CEE focused IB studies, therefore our results confirm TCE logic in this CEE context especially during the early transition time period of the 1990s which represented high uncertainty.

Model 3 presents the regression results concerning more recent (during the 2000s) Nordic FDIs in CEE countries. The explanatory power of model 3 appears to be quite good as represented by chi-square values being significant at $\mathrm{p}<0.001$ level, as well as clearly better Nagelkerke R Square value (.301) and correct classification ratio $(68.1 \%)$; both are better than earlier models. The regression results indicate that $\mathrm{R} \& \mathrm{D}$ intensity, establishment and economic size of the target country are significant and lead to similar results as shown by regression results of the full sample in the model. However, the results further indicate that in FDIs made by Nordic firms in the 2000s in the CEE region, international experience and strength of market conforming values in the target country are also significant; though they were non-significant in the previous two models. The regression coefficients indicate that high international experience of investing firms led to the choice of IJVs, while strong market 
conforming values in the target country led to the choice of WOSs by Nordic firms investing in the CEE region. These findings also confirm the findings of previous studies that used these variables to address the ownership mode choice of the firms in the CEE region (e.g. Dikova/van Witteloostuijn 2007), as well as in emerging economies generally (e.g. Arslan 2011). Therefore, international experience (based on TCE and RBV) and. strength of market conforming values in the target country (based on institutional theory) receive empirical support for their impacts on ownership mode choice in the 2000s and support our argument for analysing them together as well as testing for potential differences before and after the transition time period. We would also like to mention that the significance of strength of market conforming values for ownership mode choice of Nordic firms for FDIs made in the 2000s can be explained by referring to specific history of transition to market economy in CEE countries (see e.g. Peng 2003; Meyer/Peng 2005). CEE countries opened up for FDI in 1990, so during the $1990 \mathrm{~s}$, market conforming values were in process of development due to transition to market economy and hence their non-significance can be understandable. However, during the 2000s, many of the target countries in CEE had successfully gone through the transition process and had fully working market economy institutions (Zweynert/Goldschmidt 2006), which is also evident by the statistical significance of this important determinant. Hence, we also receive partial support for hypotheses $3 \mathrm{~b}$ and 10 in our analysis of the subsample based on the FDIs made in the 2000s.

We would like to explain the different findings regarding ownership mode choice of firms from Nordic countries in the CEE region during the 1990s and 2000 s by referring to many past studies where the 1990s have been mentioned as a relatively turbulent and difficult time period of transition for most economies in that region (see e.g. Meyer 2002, Peng 2003; Kshetri 2010). Therefore, the significance of different determinants of ownership mode choice during the 1990s and 2000s in our study is logical and in line with the argument of past CEE specific research. Finally, based on the regression results of the full sample, as well as the sub-samples, we can observe that study hypotheses 1,2 , $3 \mathrm{~b}, 6,8,9$, and 10 either received full support or have been partially supported in sub-samples. Therefore, most of the selected determinants of ownership mode choices of Nordic firms in the CEE region based on three theoretical perspectives received statistical support.

\section{Conclusions, implications and future research directions}

Firms face a critical decision concerning the ownership mode choice (WOS vs. IJV) when entering new foreign markets using FDI mode. A review of past IB studies concentrating on the CEE region reveals that the ownership mode choice of MNEs has so far received relatively less attention from the researchers compared to the analysis in other developed (e.g. Western Europe, North 
America) as well as emerging economies (Asia and especially China). Moreover, past IB studies concentrating on the CEE region lack a rather comprehensive analysis where the determinants of ownership mode choices from different theoretical paradigms are analysed together. Recognizing this gap in market entry literature for the CEE region, our paper has integrated the determinants of ownership mode choice of firms found important in past studies and developed hypotheses to be tested in a relatively unique empirical setting. We would like to further stress the fact that our paper advances the application of TCE, RBV and institutional theory in IB as well as in CEE specific studies. Along with different results for certain important determinants compared to past IB studies, our study also found certain determinants tend to become significant during certain time periods by also analysing the ownership mode choices separately for FDIs in the 1990s vs. FDIs in the 2000s. For FDIs made in the 1990 s, the results indicated that high economic growth in a target country leads to WOS formation while target country risk and parent firm product diversity lead to IJV formation. In case of FDIs made in the 2000s, R\&D intensity, economic size and strength of market conforming values lead to WOS formation while international experience leads to IJV preference by the investing Nordic firms. These findings are in line with Peng (2003), who mentioned that behaviour and strategies of foreign firms in the CEE region during the 1990s was different from later years because of the transition to market economy. Hence, for the analysis of different firm strategies in the CEE region, it is important to differentiate the early stages of transition from the later ones, as risk and uncertainty were higher in the early stages (1990s), which also impacted strategies of the firms operating there. The theoretical implication of these findings links to the fact that timing is an important element for testing established IB theories in transition and emerging economies. This influences the significance or non-significance of certain important entry mode determinants even though they may be based on theoretical reasoning from established IB theories. Hence, the timing issue needs further region specific exploration in future because it will also augment the scholarly understanding of market entry mode choices of the firms from the perspective of different IB theories.

Table 3: Summary of results

\begin{tabular}{|l|l|l|l|l|}
\hline Variables & \multirow{2}{*}{$\begin{array}{l}\text { Expecte } \\
\text { d sign }\end{array}$} & & \multicolumn{2}{|l|}{ Results } \\
\cline { 3 - 5 } & & $\begin{array}{l}\text { Full } \\
\text { Sample }\end{array}$ & $\begin{array}{l}\text { 1990s } \\
\text { FDIs }\end{array}$ & $\begin{array}{l}\text { 2000s } \\
\text { FDIs }\end{array}$ \\
\hline H1: R\&D intensity & + & + & NS & + \\
\hline $\begin{array}{l}\text { H2: Parent firm product } \\
\text { diversity }\end{array}$ & - & NS & - & NS \\
\hline H3: International & & & & \\
\hline
\end{tabular}




\begin{tabular}{|c|c|c|c|c|}
\hline experience & & & & \\
\hline $3 \mathbf{a}$ & + & NS & NS & - \\
\hline $\mathbf{3 b}$ & - & NS & NS & - \\
\hline \multicolumn{5}{|l|}{$\begin{array}{l}\text { H4: Area specific } \\
\text { experience }\end{array}$} \\
\hline $4 \mathbf{a}$ & + & NS & NS & $\mathrm{NS}$ \\
\hline $4 \mathrm{~b}$ & - & NS & NS & NS \\
\hline \multicolumn{5}{|l|}{$\begin{array}{l}\text { H5: Target country } \\
\text { experience }\end{array}$} \\
\hline $5 \mathbf{a}$ & + & NS & NS & NS \\
\hline $5 \mathbf{b}$ & - & NS & NS & NS \\
\hline H6: Target country risk & - & - & - & NS \\
\hline \multicolumn{5}{|l|}{ H7: Cultural distance } \\
\hline $7 \mathbf{a}$ & + & NS & NS & NS \\
\hline $7 b$ & - & NS & NS & NS \\
\hline H8: Economic size & + & + & NS & + \\
\hline H9: Economic growth & + & + & + & NS \\
\hline $\begin{array}{l}\text { H10: Strength of Market } \\
\text { Conf. Values }\end{array}$ & + & NS & NS & + \\
\hline H11: EU Membership & + & NS & NA & NS \\
\hline $\begin{array}{l}\text { H12: Establishment mode } \\
\text { (ACQ) }\end{array}$ & NS & - & - & - \\
\hline
\end{tabular}

It should be further noted that the non-significance of certain determinants found significant in past ownership mode choice studies concentrating on different empirical settings (e.g. Hill et al. 1990; Taylor et al. 1998; Brouthers et al. 2008; Chiao et al. 2010; Lee 2010) supports our argument about the importance of considering empirical context in analysing IB decisions and strategies for the firms. Our study is the first of its kind to analyse ownership mode choices of the firms belonging to all four Nordic countries (i.e. Finland, Sweden, Norway and Denmark) in the CEE region. All the Nordic countries represent small, open and highly internationalized economies. Therefore, the findings of our study can be generalized more easily to the firms from a similar background as the strategic decisions in FDI ownership mode choice of firms from these small and open economies tend to differ from the firms from large economies like USA, Germany, UK and Japan.

Our study also offers some interesting insights for the managers. In our study, the significance of several independent variables for the ownership mode choice 
of Nordic firms differed for the FDIs made in the 1990s and the 2000s. Therefore, for managers of Nordic firms interested to enter CEE markets, the relevance of results concerning recent FDIs is more important, which also justifies additional analysis done in this study by dividing the sample. Another interesting managerial implication relates to the significance of the establishment mode variable. Therefore, managers of new entrants should consider both of the important choices in conjunction with each other, rather than separately. This would also help them to develop a generalized FDI entry mode strategy of their firms in the CEE region, as well as mimic the often used rather successful combination of establishment and ownership mode choices of other firms from the Nordic region already operating there.

It has been mentioned earlier that determinants like cultural distance, area and target country specific experience and membership of the EU appear to be nonsignificant for ownership mode choice of Nordic firms in our study. A possible explanation for these results is that we analysed only direct effects of various variables on the ownership choices. Therefore, it is recommended for future studies to perform more in-depth analysis of the interaction or moderating effects of various variables on the ownership mode choices. Furthermore, this study did not address FDI motives, as well as several other important firm level variables like size of investing firms, as well as relative size of investment, which can be considered as a limitation. However, future studies can enrich IB as well as CEE literature by including these important variables in their analysis of FDI ownership mode choices of Nordic firms. Finally, for future studies, the comparisons with determinants of FDI ownership choices of firms from other countries representing small, open and highly internationalized economies like the Netherlands, Austria and Belgium with Nordic ones in the CEE region can also add interesting insights to the IB and market entry literature.

\section{Notes}

[1] According to OECD classifications, a branch is considered as high-tech if on average it spends at least 4 per cent of its value added for R\&D. A branch using on average 1 to 4 per cent is classified as medium-tech. The rest are low-tech branches. The following branches are classified as high-tech using the statistics provided by Nordic Statistical Secretariat: SIC 2833-2834, 3573-3574, 3579, 36, 37, and 38; Medium-tech branches are: all 28 except $2833 \&$ 2834, 30, 3339, $3341,3356-3357,3369,35$ except 3573-3574 and 3579, 39. The rest are classified as low-tech branches.

Appendix: Descriptive Statistics (Means, Standard Deviations and Binomial Correlations). $N=720$ 


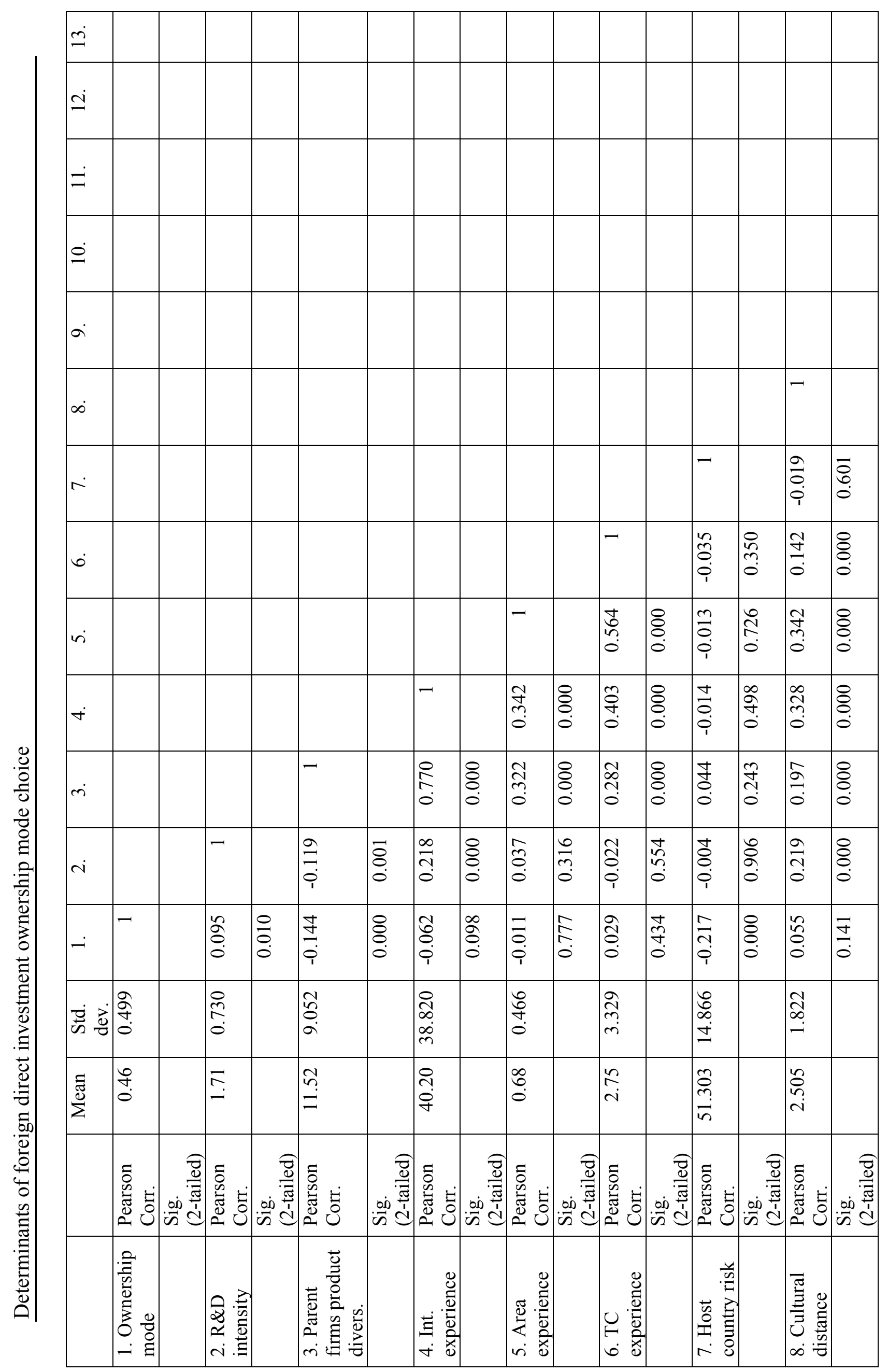




\begin{tabular}{|c|c|c|c|c|c|c|c|c|c|}
\hline & & & & & & & & - & \\
\hline & & & & & & & - & $\begin{array}{l}\infty \\
\tilde{\sigma} \\
0 \\
0 \\
1\end{array}$ & $\begin{array}{l}0 \\
\stackrel{n}{n} \\
\stackrel{0}{0} \\
0\end{array}$ \\
\hline & & & & - & & $\frac{8}{\frac{8}{0}}$ & $\hat{8}$ & $\begin{array}{l}n \\
\tilde{z} \\
0 \\
0\end{array}$ & $\frac{F}{\mathscr{O}}$ \\
\hline & & - & & $\begin{array}{l}\text { N̦ } \\
\text { N̂} \\
0 \\
1\end{array}$ & ஓ & $\frac{2}{2}$ & ஜ & $\begin{array}{l}0 \\
0 \\
0 \\
0\end{array}$ & $\begin{array}{l}\tilde{N} \\
\tilde{\sigma} \\
0 \\
0\end{array}$ \\
\hline- & & ڤે & ஜ & $\begin{array}{l}\infty \\
\stackrel{一}{N} \\
0\end{array}$ & ஜ & 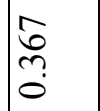 & ஜ & $\frac{\Delta}{0}$ & $\vec{F}$ \\
\hline $\begin{array}{l}\infty \\
\infty \\
\\
\end{array}$ & ஜ & 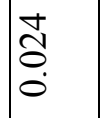 & $\stackrel{\hat{a}}{\stackrel{\sigma}{o}}$ & \begin{tabular}{l}
$n$ \\
$\infty$ \\
\hdashline \\
$\dot{0}$
\end{tabular} & ஜ & $\begin{array}{l}0 \\
\stackrel{2}{1} \\
1\end{array}$ & $\underset{0}{0}$ & $\begin{array}{l}2 \\
0 \\
0 \\
0 \\
1\end{array}$ & $\begin{array}{c}1 \\
\text { ๙ે} \\
0\end{array}$ \\
\hline 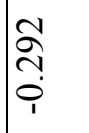 & 离 & 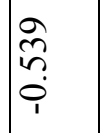 & 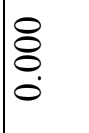 & $\begin{array}{l}n \\
\\
n \\
0 \\
1\end{array}$ & ஜ & $\begin{array}{l}\tilde{\infty} \\
\infty \\
\sim \\
0 \\
1\end{array}$ & ஜ & 色 & $\stackrel{n}{n}$ \\
\hline$\frac{1}{\frac{1}{0}}$ & \& & $\frac{\grave{\Xi}}{\stackrel{0}{0}}$ & ஜ & $\begin{array}{l}\infty \\
\text { సે} \\
0 \\
1\end{array}$ & ठ & $\begin{array}{l}0 \\
0 \\
0 \\
0\end{array}$ & $\begin{array}{l}2 \\
\hat{0} \\
0\end{array}$ & $\frac{1}{0}$ & 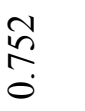 \\
\hline $\begin{array}{l}\stackrel{0}{\prime} \\
\overrightarrow{0}\end{array}$ & $\begin{array}{l}0 \\
\tilde{O} \\
0 \\
0\end{array}$ & $\underset{\Delta}{\stackrel{\Delta}{0}}$ & $\frac{\vec{R}}{0}$ & $\begin{array}{l}\infty \\
\infty \\
0 \\
0\end{array}$ & ஜ & $\frac{J}{ \pm}$ & @ & $\begin{array}{l}1 \\
0 \\
0 \\
0\end{array}$ & 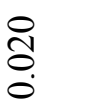 \\
\hline$\underset{\delta}{\tilde{\delta}}$ & \begin{tabular}{l}
7 \\
\multirow{n}{n}{} \\
0 \\
0
\end{tabular} & @ & $\overline{\hat{\sigma}}$ & $\begin{array}{l}n \\
\curvearrowright \\
\hat{n} \\
0 \\
1\end{array}$ & @ & $\begin{array}{l}\tilde{y} \\
\tilde{\sigma} \\
0 \\
0\end{array}$ & $\begin{array}{l}0 \\
\stackrel{n}{n} \\
0 \\
0\end{array}$ & $\begin{array}{l}0 \\
\stackrel{0}{0} \\
0 \\
0\end{array}$ & $\begin{array}{l}\hat{\infty} \\
\stackrel{0}{0} \\
0\end{array}$ \\
\hline $\begin{array}{l}\frac{T}{S} \\
0 \\
0 \\
\dot{1}\end{array}$ & $\underset{f}{O}$ & $\begin{array}{l}2 \\
2 \\
0 \\
0 \\
1\end{array}$ & $\begin{array}{l}\infty \\
0 \\
0 \\
0 \\
0\end{array}$ & $\begin{array}{l}\infty \\
0 \\
0 \\
0 \\
1\end{array}$ & 要 & $\begin{array}{l}0 \\
0 \\
0 \\
0 \\
0\end{array}$ & 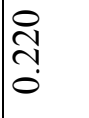 & 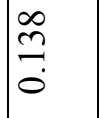 & ○ \\
\hline $\begin{array}{l}\infty \\
\infty \\
0 \\
0 \\
1\end{array}$ & 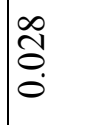 & \begin{tabular}{l}
$\infty$ \\
\multirow{0}{0}{} \\
0 \\
1
\end{tabular} & O) & $\begin{array}{l}\nexists \\
\\
0 \\
0\end{array}$ & 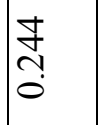 & $\begin{array}{l}0 \\
\hat{n} \\
0 \\
0 \\
1\end{array}$ & $\stackrel{m}{\exists}$ & $\stackrel{9}{\vec{O}}$ & $\begin{array}{l}8 \\
\varnothing \\
0\end{array}$ \\
\hline$\frac{\stackrel{n}{ \pm}}{\square}$ & $\begin{array}{l}8 \\
0 \\
0 \\
0\end{array}$ & 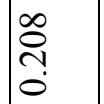 & ஜ & ठे. & $\begin{array}{l}\infty \\
\stackrel{\infty}{\infty} \\
\infty \\
0\end{array}$ & $\mid \begin{array}{l}\qquad \\
\infty \\
0 \\
0 \\
0\end{array}$ & તે. & $\frac{\infty}{\infty}$ & ¿ \\
\hline$\stackrel{2}{8}$ & & $\begin{array}{l}\infty \\
0 \\
\infty \\
r \\
r\end{array}$ & & 文 & & 究 & & ஓे & \\
\hline$\frac{m}{d}$ & & $\begin{array}{l}0 \\
\infty \\
\\
0\end{array}$ & & 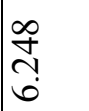 & & $\stackrel{1}{0}$ & & $\tilde{n}$ & \\
\hline 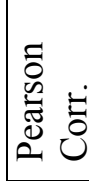 & 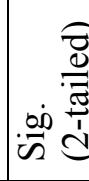 & 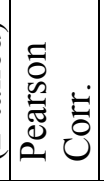 & : & 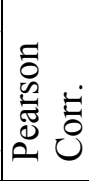 & 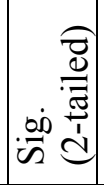 & 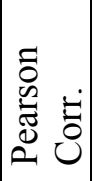 & 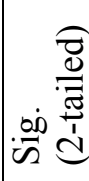 & 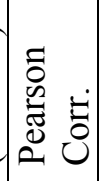 & 它 \\
\hline 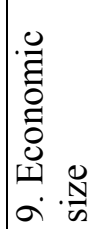 & & 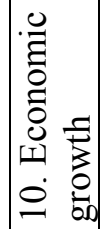 & & 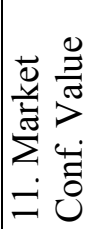 & & 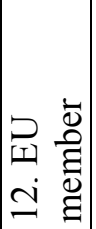 & & 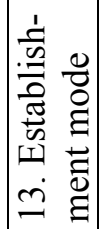 & \\
\hline
\end{tabular}




\section{References}

Agarwal, S. (1994): Socio-cultural distance and the choice of joint ventures: a contingency perspective. Journal of International Marketing, 2, 2, 63-80.

Agarwal, S./Ramaswami, S. (1992): Choice of foreign market entry: impact of ownership, location and internationalization factors. Journal of International Business Studies, 33, $1,517-551$.

Amemiya, T. (1981): Qualitative response models: a survey. Journal of Economic Literature, $19,4,1483-1536$.

Anderson, E./Gatignon, H. (1986): Modes of foreign entry: a transaction cost analysis and propositions. Journal of International Business Studies, 17, 3, 1-26.

Andersson, T./Svensson, R. (1994): Entry modes for direct investment determined by the composition of firm specific skills. Scandinavia Journal of Economics, 96, 4, 551-560.

Arslan, A. (2011): Institutional Distance- Market Conforming Values in the Host Country and Foreign Direct Investment Choices of Multinational Enterprises. Acta Wasaensia 245, Universitas Wasaensias 2011, University of Vaasa, Finland.

Arslan, A./Larimo, J. (2010): Ownership Strategy of Multinational Enterprises and the Impacts of Regulative and Normative Institutional Distance: Evidence from Finnish Foreign Direct Investments in Central and Eastern Europe. Journal of East-West Business, 16, 3, 179-200.

Arslan, A./Larimo, J. (2011): Greenfield Investments or Acquisitions: Impacts of Institutional Distance on Establishment Mode Choice of Multinational Enterprises in Emerging Economies. Journal of Global Marketing, 24, 4, 345-356.

Barkema, H. G./Bell, J. H. J./Pennings, J. M. (1996): Foreign entry, cultural barriers, and learning. Strategic Management Journal, 17, 2, 151-166.

Barkema, H.G./Vermeulen, F. (1998). International expansion through start-up or acquisition: A learning perspective, Academy of Management Journal, 41,1, 7-26.

Belsley, D. A./Kuh, E./Welsch, R. E. (1980): Regression diagnostics: Identifying influential data and sources of collinearity. New York: Wiley.

Brouthers, K. D. (2002): Institutional, cultural, and transaction cost influences on entry mode choice and performance. Journal of International Business Studies, 33, 2, 203-221.

Brouthers, K. D./Brouthers, L. E. (2000): Acquisition or Greenfield start-up? Institutional, cultural and transaction cost influences. Strategic Management Journal, 21, 1, 89-97.

Brouthers, K. D./Brouthers, L. E./Nakos, G. (2004): How national culture influences international entry-mode choice. In "Process of Internationalization. Strategic, Cultural and Policy Perspectives" Eds. F. McDonald/M. Mayer/T. Buck. Palgrave. Houndsmills.

Brouthers, K. D./Brouthers, L. E./Werner, S. (2003): Transaction cost-enhanced entry mode choices and firm performance. Strategic Management Journal, 24, 12, 1239-1248.

Brouthers, K. D./Brouthers, L. E./Werner, S. (2008): Real options, international entry mode choice and performance. Journal of Management Studies, 45, 5, 936-960. 
Brouthers, K. D./Hennart, J.-F. (2007): Boundaries of the firm: insights from international entry mode research. Journal of Management, 33, 3, 395-425.

Buckley, P./Casson, M. (1996): An economic model of international joint venture strategy. Journal of International Business Studies, 27, Special issue, 849-876.

Burgel, O./Murray, G.C. (2000). The International Market Entry Choices of Start-up Companies in High Technology Industries. Journal of International Marketing, 8,1, $33-62$.

Chang, S. J./Rosenzweig, P. M. (2001): The choice of entry mode in sequential foreign direct investment. Strategic Management Journal, 22, 8, 747-776.

Chen, H. Y./Hu, M. Y. (2002): An analysis of determinants of entry mode and its impact on performance. International Business Review, 11, 2, 193-210.

Chen, S. S./Hennart, J.-F. (2002): Japanese investors' choice of joint ventures versus wholly owned subsidiaries in the US: the role of market barriers and firm capabilities. Journal of International Business Studies, 33, 1, 1-18.

Chiao, Y. C./Lo, F. Y./Yu, C. M. (2010): Choosing between wholly-owned subsidiaries and joint ventures of MNCs from an emerging market. International Marketing Review, $27,3,338-365$.

Child, J./Tsai, T. (2005): The dynamic between firms' environmental strategies and institutional constraints in emerging economies: Evidence from China and Taiwan. Journal of Management Studies, 42, 1, 95-125.

Cho, K. R./Padmanabhan, P. (2005): Revisiting the role of cultural distance in MNC's foreign ownership mode choice: the moderating effect of experience attributes. International Business Review, 14, 3, 307-324.

Chung, C. C/Beamish, P. W. (2005): The impact of institutional reforms on characteristics and survival of foreign subsidiaries in emerging economies. Journal of Management Studies, 42, 1, 35-62.

Claver, E./Quer, D (2005): Choice of market entry mode in China: the influence of firmspecific factors. Journal of General Management, 30, 3, 51-70.

Click, R. W. (2005). Financial and political risks in US direct foreign investment. Journal of International Business Studies, 36,5, 559-575.

Contractor, F./Kundhu, S. (1998): Modal choice in a world of alliances: analyzing organizational forms in the international hotel sector. Journal of International Business Studies, 29, 2, 325-357.

Cosset, J-C./Roy, R. (1991): The determinants of country risk ratings. Journal of International Business Studies, 22,1, 135-142.

Cui, L./Jiang, F. (2009). FDI entry mode choice of Chinese firms: A strategic behavior perspective. Journal of World Business, 44,4, 434-444.

Delios, A./Beamish, P. W. (1999): Ownership strategy of Japanese firms: transactional, institutional, and experience influences. Strategic Management Journal, 20, 915-933.

Demirbag, M./Glaister, K./Tatoglu, E. (2007): Factors influencing perceptions of performance: The case of western FDI in an emerging market. International Business Review, 16, 3, 310-336. 
Dikova, D./van Witteloostuijn, A. (2007): Foreign direct investment mode choice: entry and establishment modes in transition economies. Journal of International Business Studies, 38, 6, 1013-1033.

Dowell, G./Killaly, B. (2009): Effect of resource variation and firm experience on market entry decisions: evidence from U.S. telecommunication firm's international expansion decisions. Organization Science, 20, 1, 69-84.

Estrin, S./Baghdasaryan, D./Meyer, K. E. (2009). The Impact of Institutional and Human Resource Distance on International Entry Strategies. Journal of Management Studies, 46, 7, 1171-1196.

Gatignon, H./Anderson, E. (1988): The multinational corporation's degree of control over foreign subsidiaries: an empirical test of a transaction cost explanation. Journal of Law, Economics, and Organization, 4, 2, 1-25.

Gomes-Casseres, B. (1985): Multinational ownership strategies. Ann Arbor UMI Press (PhD dissertation at Harvard Business School).

Gomes-Casseres, B. (1989): Ownership structures of foreign subsidiaries: theory and evidence. Journal of Economic Behavior \& Organization, 11, 1, 1-25.

Hair, J.F. Jr./Anderson, R.E./Tatham, R.L./Black, W.C. (1998). Multivariate Data Analysis, (5th Edition). Upper Saddle River, NJ: Prentice Hall.

Hennart, J.-F. (1991): The transaction costs theory of joint ventures: an empirical study of Japanese subsidiaries in the United States. Management Science, 37, 4, 483-497.

Hennart, J.-F./Larimo, J. (1998): The impact of culture on the strategy of multinational enterprises. Does national origin affect ownership decisions? Journal of International Business Studies, 29, 3, 515-538.

Hennart, J.-F./Park, Y. R. (1993): Greenfield vs. acquisition: the strategy of Japanese investors in the United States. Management Science, 39, 9, 1054-1070.

Herrmann, P./Datta, D. (2002): CEO successor characteristics and the choice of foreign market entry mode: an empirical study. Journal of International Business Studies, 33, 3, 551-569.

Herrman, P./Datta, D. K. (2006). CEO experiences: Effects on the choice of FDI entry mode. Journal of Management Studies, 43,4, 755-778.

Hill, C. L./Hwang, P./Kim, W. C. (1990): An eclectic theory of the choice of international entry mode. Strategic Management Journal, 11, 2, 117-128.

Hofstede, G. (1980): Cultures consequences. International differences in work related values. New York: Sage Publications.

Johanson, J./Vahlne, J. E. (1977): The internationalization process of the firm. A model of knowledge development and increasing foreign market commitment. Journal of International Business Studies, 8, 1, 23-32.

Kaynak, E./Demirbag, M./Tatoglu, E. (2007). Determinants of ownership based entry mode choice of MNEs: Evidence from Mongolia, Management International Review, 47,4, 505-530.

Khanna, T./Palepu, K. (2010): Winning in Emerging Markets: A Roadmap for Strategy and Execution. Cambridge, MA: Harvard University Press. 
Kim, Y./Gray, S. J. (2008): The impact of entry mode choice on foreign affiliate performance: the case of foreign MNEs in South Korea. Management International Review, 48, 2, 165-188.

Klein, S./Frazier, G./Roth, V. (1990): A transaction cost analysis model of channel integration in international markets. Journal of Marketing Research, 27, 2, 196-208.

Kogut, B./Singh, H. (1988): The effect of national culture on the choice of entry mode. Journal of International Business Studies, 19, 3, 412-432.

Kshetri, N. (2010): Business perceptions of regulative institutions in Central and Eastern Europe. Baltic Journal of Management, 5, 3, 356-377.

Larimo J. (1993). Foreign direct investment behaviour and performance. An analysis of Finnish direct manufacturing investments in OECD countries. Acta Wasaensia No. 32. University of Vaasa: Vaasa.

Larimo, J. (2000): Organizational structure in foreign markets. The impact of ownership and location specific determinants on the foreign direct investment behavior of Nordic firms. AIB Annual Conference in Phoenix, Arizona, USA.

Larimo, J. (2003): Form of investment by Nordic firms in world markets. Journal of Business Research, 56, 10, 791-804.

Lee, Y. H. (2010): A resource-based perspective of entry mode choices of electronic components industry into China. Proceedings of the International Conference on Future Information Technology and Management Engineering, 540-545.

Li, J./Yang, J./Yue, D.R. (2007): Identity, community, and audience: how wholly owned foreign subsidiaries gain legitimacy in China. Academy of Management Journal, 50, 1, 175-190.

Li, P. Y./Meyer, K. (2010): Contextualizing experience effects in international business: A study of ownership strategies. Journal of World Business, 44, 4, 370-382.

Luo, Y. D. (2001): Determinants of entry in an emerging economy: a multilevel approach. Journal of Management Studies, 38, 3, 443-472.

Makino, S./Beamish, P. W. (1998): Local ownership restrictions, entry mode choice, and FDI performance: Japanese overseas subsidiaries in Asia. Asia Pacific Journal of Management, 15, 2, 119-136.

Makino, S./Neupert, K. E. (2000): National culture, transaction costs, and the choice between joint venture and wholly-owned subsidiary. Journal of International Business Studies, $31,4,705-713$.

Meyer, K. (2001). Institutions, transaction costs, and entry mode choice in Eastern Europe. Journal of International Business Studies, 32, 2, 357-367.

Meyer, K. E. (2002). Management challenges in privatization acquisitions in transition economies. Journal of World Business, 37:4, 266-276.

Meyer, K. E./Peng, M. W. (2005): Probing theoretically into Central and Eastern Europe: transactions, resources, and institutions. Journal of International Business Studies, 36, $6,600-621$.

Morschett, D./Schramm-Klein, H./Swoboda, B (2010): Decades of research on market entry modes: what do we really know about external antecedents of entry mode choice? Journal of International Management, 16, 1, 60-77. 
Mutinelli, M.,/Piscitello, L. (1998). The Entry Mode Choice of MNEs: An Evolutionary Approach. Research Policy, 27,5, 491-506.

Padmanabhan, P./Cho, K. R. (1996): Ownership strategy for a foreign affiliate: an empirical investigation of Japanese firms. Management International Review, 36, 1, 45-65.

Padmanabhan, P./Cho, K. R. (1999): Decision specific experience in foreign ownership and establishment strategies: evidence from Japanese firms. Journal of International Business Studies, 30, 1, 25-41.

Pallant, J. (2007): SPSS survival manual: a step by step guide to data analysis using SPSS for windows. Buckingham: Open University Press.

Paul, D./Wooster, R. (2008): Strategic investments by US firms in transition economies. Journal of International Business Studies, 39, 2, 249-266.

Peng, M. W. (2003): Institutional transitions and strategic choices. Academy of Management Review, 28, 2, 275-296.

Ruiz-Moreno, F./Mas-Ruiz, F. J./Nicolau-Gonzálbez, J. L. (2007): Two-stage choice process of FDI: ownership structure and diversification mode. Journal of Business Research, $60,7,795-805$.

Shi, Y. Z./Ho, P. Y./Siu, W. S. (2001): Market entry mode selection: the experience of small Hong Kong firms investing in China. Asia Pacific Business Review, 8, 1, 19-41.

Slangen, A./Hennart, J.-F. (2007): Greenfield or acquisition entry: a review of the empirical foreign establishment mode literature. Journal of International Management, 13, 4, 403-429.

Slangen, A./Hennart, J.-F. (2008): Do multinationals really prefer to enter culturally-distant countries through greenfields than through acquisitions? The role of parent experience and subsidiary autonomy. Journal of International Business Studies, 39, 3, 472-490.

Sun, H. H. (1999): Entry modes of multinationals corporations into China's market: a socioeconomic analysis. International Journal of Social Economics, 26, 5, 642-659.

Svejnar, J. (2002). Transition economies: Performance and challenges. Journal of Economic Perspectives, 16,1, 3-28.

Tallman, S./Li, J. (1996): Effects of international diversity and product diversity on the performance of multinational firms. Academy of Management Journal, 39, 1, 179-196.

Taylor, C. R./Zhou, S./Osland, G. E. (1998): A transaction cost perspective on foreign market entry strategies of US and Japanese firms. Thunderbird International Business Review, $40,4,389-412$.

Tihanyi, L./Griffith, D. A./Russell, C. J. (2005): The effect of cultural distance on entry mode choice, international diversification, and MNE performance: a meta-analysis. Journal of International Business Studies, 36, 3, 271-283.

Trevino, L. J./Thomas, D. E./Cullen, J. (2008): The three pillars of institutional theory and FDI in Latin America: An institutionalization process. International Business Review, $17,1,118-133$.

UNCTAD (2011): World Investment Report 2011.

Vermeulen, F./Barkema, H. (2001): Learning through acquisitions. Academy of Management Journal, 44, 3, 457-476. 
Wei, Y. G./Liu, B./Liu, X. M. (2005): Entry modes of foreign direct investment in China: a multinomial logit approach. Journal of Business Research, 58, 11, 1495-1505.

Wetherill, G. B. (1986): Regression analysis with applications. London: Chapman and Hall.

Williamson, O. E. (1985): The economic institutions of capitalism: firms, markets, relational contracting. New York: The Free Press; London: Collier Macmillan Publishers.

$\mathrm{Xu}$, D./Pan, Y./Beamish, P.W. (2004). The effect of regulative and normative distances on MNE ownership and expatriate strategies. Management International Review, 44,3, 285-307.

Yiu, D./Makino, S. (2002). The choice between joint venture and wholly owned subsidiary: An institutional perspective. Organization Science, 13,6, 667- 683.

Zejan, M. C. (1988): Studies in the behavior of Swedish multinationals. Ekonomiska studier utgivna av Nationalekonomiska Institutionen Handelshögskolan vid Göteborgs Universitet nr. 23. Göteborg ( $\mathrm{PhD}$ dissertation)

Zhao, H. X./Luo, Y. D./Suh, T. (2004): Transaction cost determinants and ownership-based entry mode choice: a meta-analytical review. Journal of International Business Studies, 35, 6, 524-544.

Zweynert, J./Goldschmidt, N. (2006): The Two Transitions in Central and Eastern Europe as Processes of Institutional Transplantation. Journal of Economic Issues, 40, 4, 895-918. 